\title{
Renoprotection by Garcinia mangostana L. pericarp extract in streptozotocin-induced diabetic mice
}

\author{
A.N.M. Ansori ${ }^{1}$, R.J.K. Susilo ${ }^{2}$, S. Hayaza ${ }^{2}$, D. Winarni ${ }^{2,3}$, S.A. Husen ${ }^{2,3}$ \\ ${ }^{1}$ Faculty of Veterinary Medicine, ${ }^{2}$ Department of Biology, Faculty of Science and Technology, ${ }^{3}$ Animal Histology \\ Laboratory, Faculty of Science and Technology Universitas Airlangga, Kampus C Universitas Airlangga, 60115, Surabaya, \\ Indonesia, *Email: saikhu-a-h@fst.unair.ac.id
}

(Received April 9, 2018; Accepted June 3, 2018)

\begin{abstract}
The purpose of this study was to evaluate the renoprotective effect of the Garcinia mangostana L. pericarp extract (GMPE) on plasma creatinine and renal proximal tubules of streptozotocin-induced diabetic mice. This study used 36 male Balb/c strain mice. The samples were divided into 6 groups, namely KN (normal control), KD (diabetic control), KM (metformin control), and P (treatment group) comprising: P1 (50 mg GMPE/kg body weight), P2 (100 mg GMPE/kg body weight), as well as P3 (200 mg GMPE/kg body weight). The GMPE and metformin suspension were administered orally for 14 days on the diabetic mice. The diabetes was induced by intraperitoneal injection of STZ multiple at low-dose of $30 \mathrm{mg} / \mathrm{kg}$ body weight daily for five consecutive days. On day 15, mice were terminated. Data of plasma creatinine and renal proximal tubule damage levels or the number of swelling and necrosis cells were analyzed. Interestingly and it showed that administration of GMPE could reduce the plasma creatinine level and ameliorate renal proximal tubules of streptozotocin-induced diabetic mice. In conclusion, the renoprotective effect of GMPE in streptozotocin-induced diabetic mice was associated with the attenuation in oxidative stress and inflammatory, which also had antidiabetic and antioxidant activities.
\end{abstract}

Keywords: antioxidant, diabetic mice, Garcinia mangostana L., creatinine, renal proximal tubule Available online at http://www.vetmedmosul.com

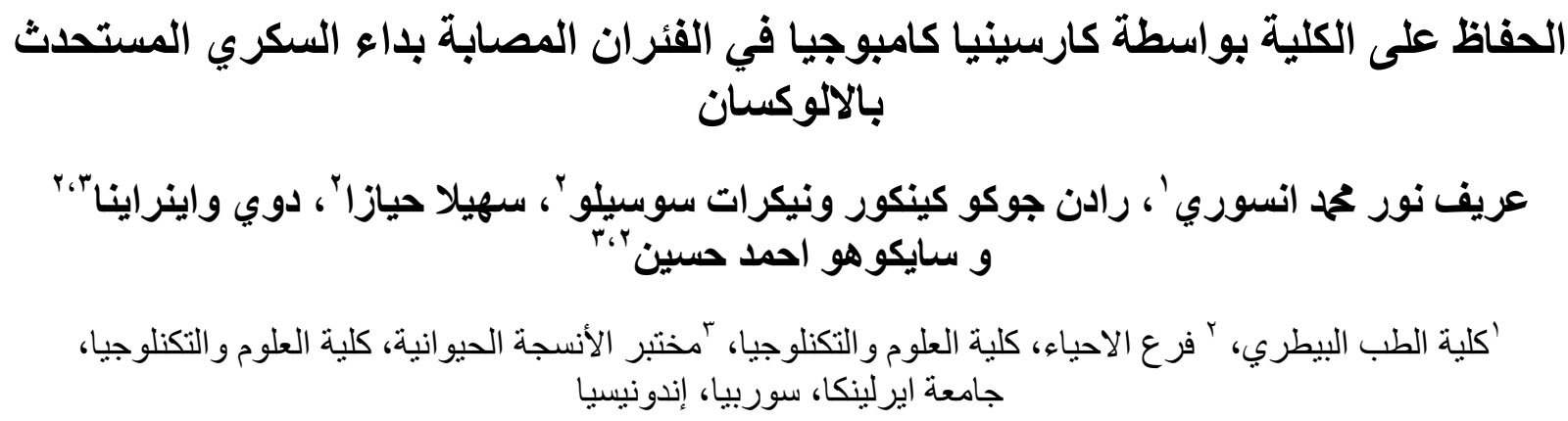

هدفت هذه الدر اسة الى تقييم التأثثر المعزز لحقن مستخلص غارسينيا مانغوستانا L. pericarp على مستوى البلازما كرياتينين و النبيبات

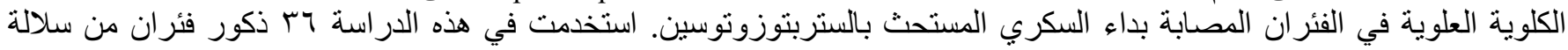

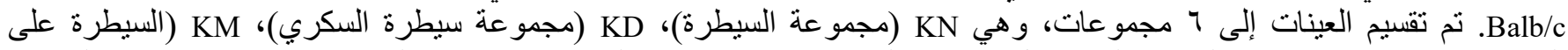

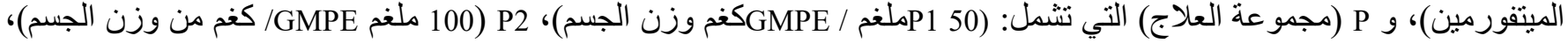

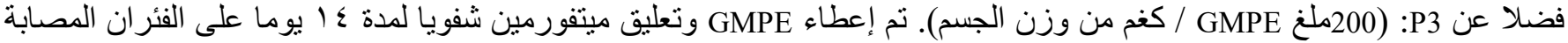

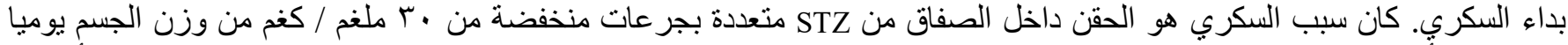

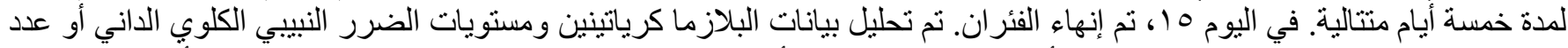

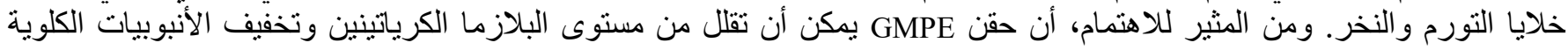




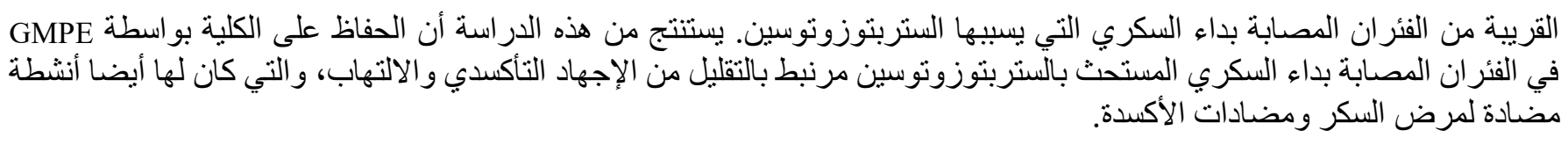

\section{Introduction}

Diabetes mellitus (DM) is a global problem that has high morbidity and mortality rates (1). In 2013, there were more than 350 million people with diabetes mellitus in all over the world and this number was predicted to raise up until 592 million people in 2035. The growth of population, population ageing, and urbanization cause life style changes, which tend to create $55 \%$ increase of people with DM all over the world in 2035 (2). According to Wild et al. (3), Indonesia has the fourth highest number of diabetic patients in the world, as many as 8.4 million people in 2000 and this number is predicted to increase to 21.3 million people by 2030 .

Indonesia is among the top 5 countries in the world that has high biodiversity of plants and around $55 \%$ of them are endemic (4). One of them is Garcinia mangostana L., a tropical fruit which has been used for hundreds of years as a traditional medicine all over the world (5). The fruits contain of some bioactive compounds such as xanthone, terpene, anthocyanin, tannin, phenol, and several vitamins (6). Some phytochemical researches showed that there are a lot of xanthone compounds in the surface of the fruits (7); such as $\alpha$-mangostin (6), $\gamma$-mangostin (8), 8-deoxygartanin, garsinon E, mangosanol (9), $\beta$-mangostin (6), tovophyllin A and $\mathrm{B}$ (10), mangostenin (11), and mangostenon C, D, and E (12).

Garcinia mangostana L. is known as the functional foods and dietary supplements that are recognized to have some benefits for health $(13,14)$. The main derivate of xanthone in Garcinia mangostana L. is $\alpha$-mangostin, this compound has various pharmacological advantages, such as antidiabetic $(13,15)$ and antioxidant $(14,16)$. The ethanol extract of Garcinia mangostana L. pericarp has an antioxidant activity and is possible to lower the glucose level in blood. The antioxidant compounds act as inhibitors which is used to deter autoxidation, thus, the best way to reduce oxidative stress is by reducing the free radicals or optimizing the body's defenses by multiplying the antioxidants (14). Furthermore, antioxidant also protects the tissue from oxidative damages (13). The oxidative stress condition in hyperglycemia lead to the increasing glucose metabolism through a polyol pathway, the increasing formation of advanced glycation end products (AGEs), the activation of protein kinase $\mathrm{C}$ ( $\mathrm{PKC})$, and the increasing transfer of excess glucose through the hexosamine pathway (17).

Several approaches which are currently available for treating diabetes including insulin therapy; such as treatment using insulin secretagogues (glimepiride), biguanides (metformin), and $\alpha$-glucosidase inhibitors (acarbose) (18). However, this therapy has some limited efficacies of side effects such as hypoglycemia and weight gain (19). Thus, researches on alternative medicine from plants becomes very crucial in order to solve this problem (20). In this study, GMPE was used to determine its antioxidant potential to lower plasma creatinine levels and repair the damage in renal proximal tubules of diabetic mice which will be used for the development of GMPE as a DM remedy.

\section{Materials and methods}

\section{Ethical statement}

Ethical approval for this study was obtained from the Committee of Animal Care and Use, Faculty of Veterinary Medicine, Universitas Airlangga, Surabaya, Indonesia (701-KE).

\section{Experimental materials}

This study used 36 male Balb/c mice, 3-4 months old, weight 25-35 g which were obtained from Faculty of Pharmacy Universitas Airlangga, Indonesia and grouped into 6 experimental groups. Each experimental group consisted of 6 mice. Non-diabetic mice were applied as the normal controls $(\mathrm{KN})$. While diabetic mice induced by STZ were divided into 3 groups, namely diabetic group (KD), metformin group (KM), and treatment group of 3 doses GMPE (P1, P2, and P3). Besides, this study also utilized the pericarp of Garcinia mangostana L. fruits which was obtained from some traditional markets in Surabaya and the materials for freeze drying, its extraction ( $96 \%$ ethanol), the hyperlipidemic induction of mice with lard (per oral), STZ (purchased from Sigma-Aldrich) which was mixed with citrate buffer (purchased from Sigma-Aldrich) and phosphate-buffered saline (purchased from Sigma-Aldrich) to induce diabetic condition in mice, standard antidiabetic drug (Metformin $\mathrm{HCl} 500 \mathrm{mg}$ ), all materials for plasma creatinine measurements, and all materials for the preparation of renal histology.

\section{Experimental tools}

The tools used in this study were standard cages for mice, drinking bottles, food boxes, husk, CX23 upright microscope (Olympus), petri dishes, analytical scale, surgical equipment, and $1 \mathrm{~mL}$ modified syringes for per oral mice treatment, $1 \mathrm{~mL}$ injection needle for blood sampling and diabetes induction, glucometer and Accu- 
Check $^{\circledR}$ Active Test strip, microtubes (Eppendorf ${ }^{\circledR}$ ), BD Vacutainer $^{\mathbb{B}}$ blood collection tubes, alcohol swabs $70 \%$, beaker glasses, filter papers, blender, stirrer, Erlenmeyer flasks, micropipette (Eppendorf ${ }^{(B)}$ ), tips (white, blue, and yellow), freeze dryer, Rotavapor ${ }^{\circledR}$ R-300, Pentra C200 (Horiba Medical), microplates, microwaveable jar, paraffin, paraffin bath, paraffin oven, microtome, object glasses and covers, dissecting set, vials, tissue, graticule, needles, and photo-microscopy device (Sony).

\section{Experimental design}

This study was an experimental research with Completely Randomized Design (CRD) conducted in Animal Laboratory, Animal Histology Laboratory, Molecular Genetics Laboratory of Faculty of Science and Technology Universitas Airlangga, and Institute of Tropical Disease (ITD) in Universitas Airlangga. The experiments are divided into 6 stages as following: 1- The extraction of Garcinia mangostana L. fruit pericarp. 2- Animal grouping and treatment. 3- Creatinine serum measurements. 4- Renal histology preparation. 5- Observation. 6- The data analysis.

The part of Garcinia mangostana L. fruit which was used as an extract is the pericarp, scraped, then made into powder with a blender. Then, macerate the powder with $96 \%$ ethanol for about 7 days. The filtrate was then filtered using filter paper, proceed to filtration, and evaporated using rotary vacuum evaporator at $50{ }^{\circ} \mathrm{C}$. Then freeze dry the evaporated viscous extract to produce a reddish color dry extract (14).

Animals were randomly divided into 6 experimental groups. Each experimental group consisted of 6 mice (6 mice/group). Non-diabetic mice were used as normal controls $(\mathrm{KN})$. While diabetic mice induced by STZ were divided into 3 groups, they were diabetic group (KD), metformin group (KM), and $\mathrm{P}$ (treatment group) which consisted of P1 (50 mg GMPE/kg body weight), P2 (100 $\mathrm{mg}$ GMPE/kg body weight), and P3 (200 mg GMPE/kg body weight). GMPE was given per orally. Treatment was given for 14 days. Diabetic condition in mice were induced by streptozotocin (STZ) in $\mathrm{pH} 4.5$ citrate buffer with multiple low-dose of $30 \mathrm{mg} / \mathrm{kg}$ body weight, intraperitoneally, for five consecutive days. Before induced by STZ, mice weight was measured. Mice weighing around 30 grams were induced with dose of $0.9 \mathrm{mg} \mathrm{STZ}$ which was dissolved in $0.15 \mathrm{~mL}$ of citrate buffer. Mice weighing 31-40 grams were induced with dose of $1.2 \mathrm{mg} \mathrm{STZ}$ which was dissolved in citrate buffer. On the $7^{\text {th }}$ and $14^{\text {th }}$ day after the last STZ injection, a fasting glucose level were measured using a glucometer. Mice which were labeled as diabetic mice were mice with the fasting blood glucose levels greater than $126 \mathrm{mg} / \mathrm{dL}(8,13,14)$.

The method used for measuring creatinine levels was the Jaffe reaction. Absorbance was measured using Pentra C200 (Horiba Medical) at $510 \mathrm{~nm}$ wavelength.
Furthermore, the histological samples of renal were performed by hematoxylin-eosin staining. The observation was performed using a microscope with 400x magnification, camera, and eyepiece graticule. Each sample was observed in three viewing zones. The observed part was the cortical region. Calculation of the tubule cells number was based on the two criteria of renal tubular epithelial cells, which were swelling and necrotic cells.

\section{Statistical analysis}

Statistical data analysis was performed using SPSS (Statistical Package for the Social Science) program which included normality test and homogeneity test using OneSample Kolmogorov-Smirnov test and Levene test. The analysis was then continued using one-way analysis of variance $(\alpha=0.05)$ and Duncan test at 0.05 or $95 \%$.

\section{Results}

The results of One-Sample Kolmogorov-Smirnov test showed that the data was normally distributed with $\mathrm{P}=$ $0.062(\mathrm{P}>0.05)$. The homogeneity test revealed that the data was homogeneous with $\mathrm{P}=0.384(\mathrm{P}>0.05)$. One-way analysis of variance presented the value of $\mathrm{P}=0.001(\mathrm{P}<$ $0.05)$. In knowing the significance among treatment groups, Duncan test was performed. The results of Duncan test on mice plasma creatinine showed that $\mathrm{KN}$ group had no significant variance compared to KM group, $\mathrm{P} 2$ group, and $\mathrm{P} 3$ group, but significantly different with $\mathrm{KD}$ group and $\mathrm{P} 1$ group.

The One-Sample Kolmogorov Smirnov test exhibited that each data of swollen and necrosis renal tubular epithelial cells had normal distributions with $\mathrm{P}=0.982$ and $\mathrm{P}=0.965(\mathrm{P}>0.05)$. The homogeneity test exposed the data was homogeneous with $\mathrm{P}=0.601, \mathrm{P}=0.869$, and $\mathrm{P}=0.344$ $(\mathrm{P}>0.05)$. One-way analysis of variance analysis for the two criteria of renal tubular epithelial cells provided the value of $\mathrm{P}=0.000(\mathrm{P}<0.05)$. On the observation of the three criteria of renal proximal tubular epithelial cells, the swollen and necrotic renal proximal tubular epithelial cells confirmed the variances among treatments. To know the significance between treatment groups, Duncan test was performed.

\section{Discussion}

STZ is a NO (nitric oxide) donor that contributes to cell damage. In addition, STZ is also capable of generating ROS and RNS which have an important role in cell damage (21). According to Yokozawa et al. (22) and Pedraza-Chaverrí et al. (23), ROS and RNS which are free radicals can disrupt the physiological function of a tissue and cause renal damage. Lee et al. (24) suggested that ROS increase and 
proinflammatory cytokines play important roles in glomeruli, tubules, and blood vessels damages.

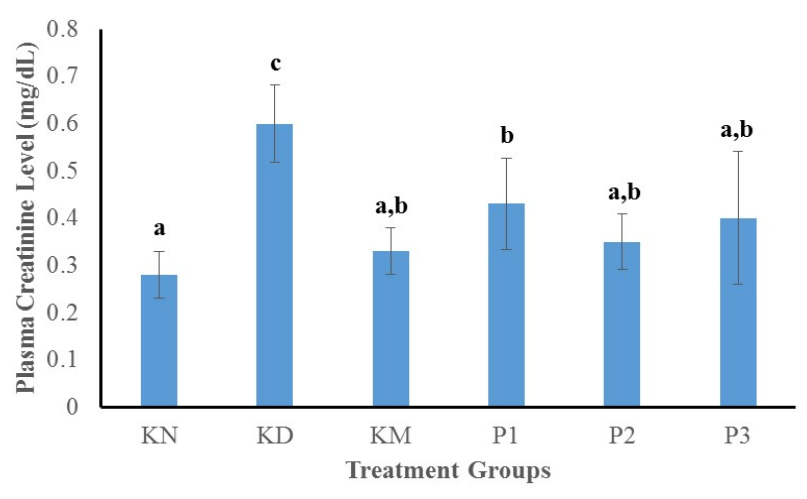

Figure 1. Diagram of plasma creatinine level. Different letters (in the graph) indicated statistically the significant variances between different treatments by Duncan's test. $\mathrm{KN}$ : normal control; KD: diabetic control; KM: metformin control; P1: $50 \mathrm{mg}$ GMPE/kg body weight; P2: $100 \mathrm{mg}$ GMPE/kg body weight; P3: $200 \mathrm{mg}$ GMPE/kg body weight.

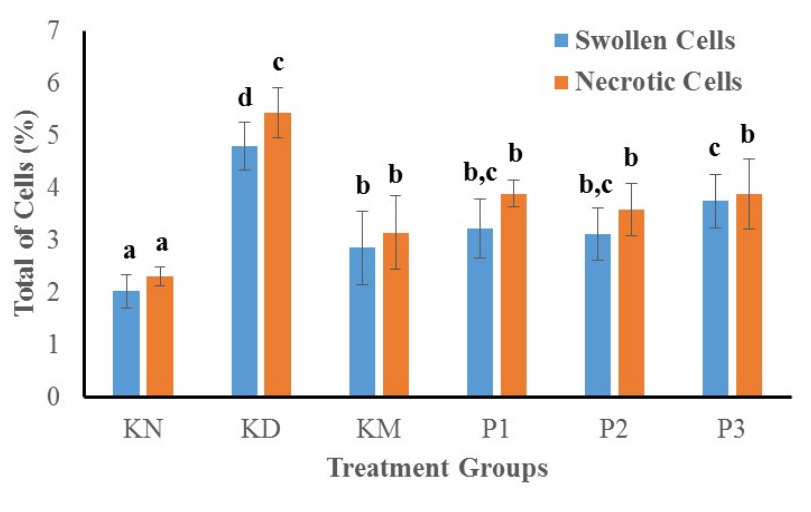

Figure 2. The mean of swollen and necrotic renal proximal tubular epithelial cells of diabetic mice. Different letters (in the graph) indicated statistically the significant variances Duncan's test between different treatments. KN: normal control; KD: diabetic control; KM: metformin control; P1: $50 \mathrm{mg}$ GMPE/kg body weight; P2: $100 \mathrm{mg} \mathrm{GMPE/kg} \mathrm{body}$ weight; P3: $200 \mathrm{mg} \mathrm{GMPE/kg} \mathrm{body} \mathrm{weight.}$
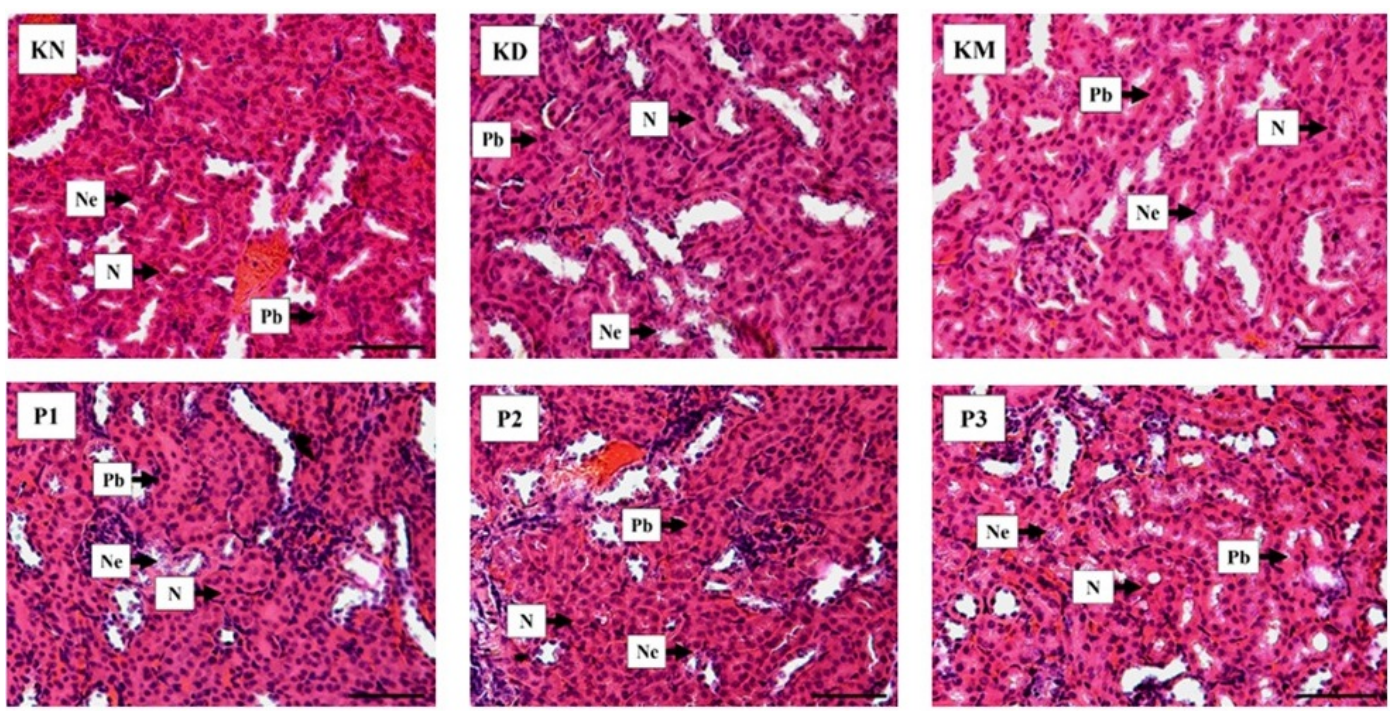

Figure 3. Histological picture of renal proximal tubules of diabetic mice. N: normal cell, Ne: necrosis cell, and Pb: swollen cell. KN: normal control; KD: diabetic control; KM: metformin control; P1: $50 \mathrm{mg}$ GMPE/kg body weight; P2: 100 mg GMPE/kg body weight; P3: $200 \mathrm{mg}$ GMPE/kg body weight. Scale bar: $60 \mu \mathrm{m}$.

A study by Zafar et al. (25) mentioned that a diabetic rat (Rattus norvegicus) injected by single dose of STZ with 45 $\mathrm{mg} / \mathrm{kg}$ body weight can cause necrosis of the tubular cells, glomerulosclerosis, tubular atrophy, and thickening of the glomerular membrane. Another study conducted by Hou et al. (26) found that the increasing levels of blood urea nitrogen (BUN) and serum creatinine in the diabetes group indicates the renal damage. Biochemical parameters correlate with renal histology studies. STZ causes significant damage to the renal histological structure, including the glomeruli and tubules. Thus, STZ injection is able to disrupt the structure and function of renal tubular epithelial cells. 
The damages of renal proximal tubular epithelial cells are a better indicator for disease progression than glomerular damage (27). Creatinine excretion is the result of two physiological processes, which are glomerular filtration and actively secreted by the renal proximal tubules. If there is a disturbance in creatinine secretion by the renal proximal tubules, then the serum creatinine levels will increase (28). On the other hand, Ozbek et al. (29) mentioned that the damage of renal histological structures causes a decrease in glomerular filtration rate (GFR). This inhibits creatinine removal from the body so that the level of creatinine in the blood increases.

Kidneys does not depend on insulin for the absorption of glucose, so the increase of blood glucose levels in diabetic conditions will produce high intracellular glucose level and cause severe and sustained hyperglycemia condition (30). The higher amount of glucose filtered by glomeruli in hyperglycemia conditions increases the burden of proximal tubule epithelial cells. In addition, proximal tubule epithelial cells cannot decrease the glucose transport rate to prevent excessive intracellular glucose in hyperglycemic conditions. Excessive uptake of glucose to the proximal tubule may inhibit reabsorption and proximal tubular secretion, resulting in the increasing serum creatinine levels (31).

Husen et al. (14) stated that the condition of hyperglycemia can disturb glucose metabolism, as well as direct reaction to other molecules in cells which lead to high oxidant formation. This condition leads to oxidative stress, a condition where there is an increase in oxidant production in the body, while the endogenous antioxidants that play a role in neutralizing the oxidant's performance are disrupted. This is consistent with Winiarska et al. (32) who mentioned that hyperglycemia is associated with the increasing production of ROS and produces the oxidative stress conditions that allegedly play a key role in the pathogenesis of this disorder. According to Ceriello (17), four keys to biochemical changes activated through oxidative stress conditions in hyperglycemia are the increased glucose metabolism through polyol pathways, the increased formation of advanced glycation end products (AGEs), the activation of protein kinase $\mathrm{C}$ (PKC), and the increased transport of excess glucose through hexosamine pathway. These biochemical changes will further worsen the formation of free radicals which affect the occurrence of damages in the body of people with diabetes. A study conducted by Li et al. (33) stated that the activation of the PKC can induce damage to the renal proximal tubular epithelial cells.

During diabetic conditions, the increasing blood glucose levels contribute to the formation of AGEs and ROS production. Advanced glycation end products also produce ROS (34) and both are associated with cell death, tissue damage, and renal dysfunction. The hyperglycemic condition activates the polyol pathway and produces fructose from glucose. Fructose and its metabolites as well as glucose are involved in the non-enzymatic glycation of cellular proteins. The resulted Schiff base undergoes a rearrangement of the structure to form the Amadori product which later produces the $\alpha$-dicarbonyl compound and AGEs by cross-linking with other proteins $(35,36)$. On the other hand, Stevens et al. (37) mentioned that in diabetic condition, the sorbitol pathway activity is increased in the tissues which do not require insulin to uptake its cellular glucose, for example in the kidneys. Sorbitol cannot pass through the cell membranes easily, accumulated, and causes the osmotic damage to the cells (swelling). The accumulation of sorbitol decreases myo-inositol, which can interfere cell osmoregulation so that the cell is damaged.

Phytochemical screening for ethanol extract of Garcinia mangostana L. pericarp is known for containing groups of alkaloids, flavonoids, glycosides, saponins, tannins, and steroids/triterpenoids (38). The ethanol extract of Garcinia mangostana L. pericarp has antioxidant, anti-inflammatory, and antidiabetic activities (14). According to Husen et al. (13), antioxidants can protect the tissues from oxidative damage which caused by hyperglycemia. The mechanism of antioxidant ability in binding the free radical due to the presence of hydroxyl groups and its role as a hydrogen donor for the free radicals.

In the P1 group, the mean plasma creatinine levels were significantly different from the KN and KD groups but had no significant variance from the KM group, $\mathrm{P} 2$ group, and P3 group. According to Pasaribu et al. (38), the increased dose of the drug should increase the response proportionally to the increased dose, but by increasing the doses, the increase in response will eventually decrease as it already achieves doses which cannot improve the response anymore. This situation happens often in the natural medicines because the compounds contain not just one but various chemical compounds. Those compounds work together to create an effect. However, by increasing the doses, the number of chemical compounds contained are also increasing and resulting in some adverse interactions which cause lower effects.

The mean of plasma creatinine levels in the P2 group was significantly different from KD group and $\mathrm{P} 1$ group, but it had no significant variances with the KN group, $\mathrm{KM}$ group, P2 group, and P3 group. This was because the antioxidant chemical compounds in GMPE were able to effectively reduce the oxidative stress conditions and fix the damage on the renal histological structure, so that the glomerular filtration rate and creatinine secretion in the proximal tubule return to normal and lower the plasma creatinine levels. Husen et al. (13) stated that the mechanism of antioxidant ability to increase free radical is due to the presence of hydroxyl groups and its action as a hydrogen donor for the free radicals. A study conducted by 
Perez-Rojas et al. (39) showed that $\alpha$-mangostin has the nephroprotective effects of nephrotoxic compounds and $\alpha$ mangostin supplementation significantly reduces oxidative stress, histological structure damage, and renal dysfunction. However, the results of study conducted by Pasaribu et al. (38) mentioned that the ethanol extract of Garcinia mangostana L. pericarp with the dose of $100 \mathrm{mg} / \mathrm{kg}$ body weight is more effective in lowering blood glucose levels compared to the doses of 50,200 , and $400 \mathrm{mg} / \mathrm{kg}$ body weight.

In the P3 group, the mean of plasma creatinine levels was significantly different from the diabetic group of KD but had no significant variances with the KN group, KM group, $\mathrm{P} 1$ group, $\mathrm{P} 2$ group, and $\mathrm{P} 3$ group. This was possible because the contained antioxidants at dose of $50 \mathrm{mg} / \mathrm{kg}$ body weight was not sufficient and not effective in reducing the oxidative stress conditions and repairing the histological damage of renal structure which had the implications to renal physiology. The results of research conducted by Pasaribu et al. (38) confirmed that the ethanol extract of Garcinia mangostana L. pericarp at the doses of 200 and $400 \mathrm{mg} / \mathrm{kg}$ body weight was not followed by an increase in antidiabetic activity.

The results of this study indicated that the effect of Garcinia mangostana L. pericarp extract had an effect in lowering the plasma creatinine level of diabetic mice. According to Jujun et al. (40), the consumption of Garcinia mangostana L. pericarp ethanol extract with the dosage 50$1000 \mathrm{mg} / \mathrm{kg}$ body weight for 28 days showed no significant toxic effect. In addition, Sudjarwo and Koerniasari (41) argued that flavonoids, saponins, and triterpenoids allegedly assist the process of repairing glomeruli and tubules that have been damaged so that the filtration and creatinine secretion would return to normal. The ethanol extract of Garcinia mangostana L. pericarp has a potential nephroprotective effect and can reduce the effects of nephrotoxic compounds caused by the lead acetate exposure. Another study conducted by Perez-Rojas et al. (39) which also used mice showed that $\alpha$-mangostin has a nephroprotective effect on cisplatin which has nephrotoxicity properties. Husen et al. (42) stated that supplementation of $\alpha$-mangostin significantly reduces oxidative stress, histological structural damage, and renal dysfunction.

\section{Conclusion}

According to this study, it can be concluded that giving various doses of GMPE which contains antioxidant is potentially lowering the plasma creatinine level and ameliorating the damages of renal histological structure in the diabetic mice. The dose of $100 \mathrm{mg} / \mathrm{kg}$ body weight is more effective to lower the plasma creatinine level and to repair the renal histological structure of diabetic mice because it contains the xanthone antioxidant compound.
The main compound of the Garcinia mangostana L. pericarp is the xanthone groups. These compound groups have pharmacological activities such as antidiabetic, antioxidants, and anti-inflammatory.

\section{Authors' Contributions}

Arif Nur Muhammad Ansori, Dwi Winarni, and Saikhu Akhmad Husen designed the experiments. Arif Nur Muhammad Ansori, Raden Joko Kuncoroningrat Susilo, and Suhailah Hayaza performed the experiments. Arif Nur Muhammad Ansori and Saikhu Akhmad Husen wrote the manuscript. All authors read and approved the manuscript.

\section{Acknowledgement}

We thank Firas Khaleyla, Septian Hary Kalqutny, and Theo Herdika Putra for excellent technical assistance and Dewi Sartika for editing the manuscript.

This work was supported by the Ministry of Research, Technology, and Higher Education of the Republic of Indonesia. Special thanks to PMDSU Scholarship - Batch III (awarded to Arif Nur Muhammad Ansori, Raden Joko Kuncoroningrat Susilo, and Suhailah Hayaza).

\section{Competing Interests}

The authors declared that they have no competing interests.

\section{References}

1. Kang KS, Lee W, Jung Y, Lee JH, Lee S, Eom DW, Jeon Y, Yoo HH, Jin MJ, Song KI, Kim WJ, Ham J, Kim HJ, Kim SN. Protective effect of esculin on streptozotocin-induced diabetic renal damage in mice. $\mathrm{J}$ Agri Food Chem. 2014;62:2069-2076.

2. Guariguata L, Whiting DR, Hambleton I, Beagle J, Linnenkamp U, Shaw JE. Global estimates of diabetes prevalence for 2013 and projections for 2035 for the IDF Diabetes Atlas. Diab Res Clin Pract. 2014;103:137-149.

3. Wild S, Roglic G, Green A, Secree R, King H. Global prevalence of diabetes. Diabe Care. 2004;27:1047-1053.

4. Ministry of Environment and Forestry of Indonesia. The Fifth National Report to The Convention on Biological Diversity. Deputy Minister of Environmental Degradation Control and Climate Change, Ministry of Environment and Forestry of Indonesia. 2014.

5. Pedraza-Chaverrí J, Cárdenas-Rodríguez N, Orozco-Ibarra M, PérezRojas JM. Medicinal properties of mangosteen (Garcinia mangostana). Food Chem Toxicol. 2008;46:3227-3239.

6. Chin YW, Jung HA, Chai H, Keller WJ, Kinghorn AD. Xanthones with quinone reductase-inducing activity from the fruits of Garcinia mangostana (Mangosteen). Phytochem. 2008;69:754-758.

7. Jung HA, Su BN, Keller WJ, Mehta RG, Kinghorn AD. Antioxidant xanthones from the pericarp of Garcinia mangostana (Mangosteen). J Agri Food Chem. 2006;54:2077-2082.

8. Husen SA, Winarni D, Salamun, Ansori ANM, Susilo RJK, Hayaza S. Hepatoprotective effect of gamma-mangostin for amelioration of impaired liver structure and function in streptozotocin-induced diabetic mice. IOP Conf Ser: Earth Environ Sci. 2019;217:012031. 
9. Chairungsrilerd N, Takeuchi K, Ohizumi Y, Nozoe S, Ohta T. Mangosanol, a prenyl xanthone from Garcinia mangostana. Phytochem. 1996;43(5):1099-1102.

10. Huang YL, Chen CC, Chen YJ, Huang RL, Shieh BJ. Three xanthones and a benzophenone from Garcinia mangostana. J Natl Prod. 2001;64(7):903-906.

11. Suksamrarn S, Suwannapoch N, Phakhodee W, Thanuhiranlert J, Ratananukul P, Chimnoi N, Suksamrarn A. Antimycobacterial activity of phenylated xanthones from the fruits of Garcinia mangostana. Chem Pharmaceut Bull. 2003;51(7):857-859.

12. Suksamrarn S, Komutiban O, Ratananukul P, Chimnoi N, Lartpornmatulee N, Suksamrarn A. Cytotoxic prenylated xanthones from the young fruit of Garcinia mangostana. Chem Pharmaceut Bull. 2006;54:301-305.

13. Husen SA, Winarni D, Khaleyla F, Kalqutny SH, Ansori ANM. Activity assay of mangosteen (Garcinia mangostana L.) pericarp extract for decreasing fasting blood cholesterol level and lipid peroxidation in type- 2 diabetic mice. AIP Conference Proceedings $2017 ; 1888$.

14. Husen SA, Kalqutny SH, Ansori ANM, Susilo RJK, Alymahdy AD, Winarni D. Antioxidant and antidiabetic activity of Garcinia mangostana L. pericarp extract in streptozotocin-induced diabetic mice. Biosci Res 2017;14(4):1238-1245.

15. Nelli GB, Solomon AK, Kilari EK. Antidiabetic effect of $\alpha$-mangostin and its protective role in sexual dysfunction of streptozotocin induced diabetic male rats. Sys Biol Rep Med. 2013;59(6):319-328.

16. Jariyapongskul A, Areebambud C, Suksamrarn S, Mekseepralard C. Alpha-mangostin attenuation of hyperglycemia-induced ocular hypoperfusion and blood retinal barrier leakage in the early stage of type 2 diabetes rats. BioMed Res Inter. 2015;2015:1-10.

17. Ceriello A. Diabetic complications: from oxidative stress to inflammatory cardiovascular disorders. Medicographia. 2011;33:2934.

18. Cheng AYY, Fantus IG. Oral antihyperglycemic therapy for type 2 diabetes mellitus. Cana Med Ass J. 2005;172:213-226.

19. Moller DE. New drug targets for type 2 diabetes and the metabolic syndrome. Nat. 2001;414:821-827.

20. Wahyuni DK, Ansori ANM, Vidiyanti F. GC-MS analysis of phytocomponents in methanolic extracts of leaf-derived callus of Justicia gendarussa Burm.f. Biosci Res. 2017;14(3):668-677.

21. Szkudelski T. The mechanism of alloxan and streptozotocin action in $\beta$-cells of the rat pancreas. Physiol Res. 2001;50:537-546.

22. Yokozawa T, Kim HY, Nonaka G, Kosuna K. 2002. Buckwheat extract inhibits progression of renal failure. J Agr Food Chem. 2002;50(11):3341-3415.

23. Pedraza-Chaverrí J, Barrera D, Maldonado PD, Chirino YI, MacíasRuvalcaba NA, Medina-Campos ON, et al. S-allylmercaptocysteine scavenges hydroxyl radical and singlet oxygen in vitro and attenuates gentamicin-induced oxidative and nitrosative stress and renal damage in vivo. BMC Clin Pharmacol. 2004;4.

24. Lee KE, Kim EY, Kim CS, Choi JS, Bae EH, Ma SK, Kim KK, Lee JU, Kim SW. Macrophage-stimulating protein attenuates gentamicininduced inflammation and apoptosis in human renal proximal tubular epithelial cells. Biochem Biophys Resh Com. 2013;434:527-533.

25. Zafar M, Naqvi SN, Ahmed M, Kaimkhani ZA. Altered kidney morphology and enzymes in streptozotocin induced diabetic rats. Inter J Morphol. 2009;27(3):783-790.
26. Hou S, Liang C, Liu H, Zhu D, Wu Y, Liang J, Zhao Y, Guo J, Huang S, Lai X. Dendrobium officinale prevents early complications in streptozotocin-induced diabetic rats. Evid Based Complement Alternat Med. 2016;2016:6385850.

27. Marcussen N. Tubulointerstitial damage leads to atubular glomeruli: significance and possible role in progression. Nephrol Dial Transplan. 2000;15(6):74-75.

28. Musso CG, Michelángelo $\mathrm{H}$, Vilas M, Reynaldi J, Martinez B, Algranati L, Macías NJF. 2009. Creatinine reabsorption by the aged kidney. Intern Urol Nephrol. 2009;41:727-731.

29. Ozbek E, Cekmen M, Ilbey YO, Simsek A, Polat EC, Somay A. Atorvastatin prevents gentamicin-induced renal damage in rats through the inhibition of p38-MAPK and NF-kappaB pathways. Renal Fail. 2009;31(5):382-92.

30. Chandra D, Jackson EB, Ramana KV, Kelley R, Srivastava SK, Bhatnagar A. Nitric oxide prevents aldose reductase activation and sorbitol accumulation during diabetes. Diab. 2002;51:3095-3101.

31. Vallon V. The proximal tubule in the pathophysiology of the diabetic kidney. Am J Physiol Reg Integ Comp Physiol. 2011;300: R1009R1022.

32. Winiarska K, Szymanski K, Gorniak P, Dudziak M, Bryla J. Hypoglycaemic, antioxidative, and nephroprotective effects of taurine in alloxan diabetic rabbits. Biochim. 2009;91:261-270.

33. Li X, Pabla N, Wei Q, Dong G, Messing RO, Wang C, Dong Z. PKC$\delta$ promotes renal tubular cell apoptosis associated with proteinuria. $\mathrm{J}$ Am Soc Nephrol. 2010;21:1115-1124.

34. Forbes JM, Coughlan MT, Cooper ME. Oxidative stress as a major culprit in kidney disease in diabetes. Diab. 2008;57:1446-1454.

35. Schaffer J, Azuma J, Mozaffari M. Role of antioxidant activity of taurine in diabetes. Cana J Physiol Pharmacol. 2009;87:91-99.

36. Palsamy P, Subramanian S. Resveratrol protects diabetic kidney by attenuating hyperglycemia-mediated oxidative stress and renal inflammatory cytokines via Nrf2-Keap1 signaling. Biochimica et Biophysica Acta. 2011;1812:719-731.

37. Stevens MJ, I Obrosova, EL Feldman and DA Greene. The sorbitol osmotic and sorbitol-redox hypothesis. In: Diabetes Mellitus: a Fundamental and Clinical Text. Philadelphia: Lippicott Williams \& Wilkins; 2000. pp.972-983.

38. Pasaribu F, Sitorus P, Bahri S. The test of ethanol of mangosteen rind (Garcinia mangostana L.) to decrease blood glucose level. J Pharmaceut Pharmacol. 2012;1(1):1-8.

39. Perez-Rojas JM, Cruz C, Garcia-Lopez P, Sanchez-Gonzalez DJ, Martinez-Martinez CM, Ceballos G, Espinosa M, Melendez-Zajgla J, Pedraza-Chaverri J. Renoprotection by alpha-mangostin is related to the attenuation in renal oxidative/nitrosative stress induced by cisplatin nephrotoxicity. Free Rad Res. 2009;43:1122-1132.

40. Jujun P, Pootakham K, Pongpaibul Y, Duangrat C, Tharavichitkul P. Acute and repeated dose 28-day oral toxicity study of Garcinia mangostana Linn. rind extract. Chiang Mai Uni J Nat Sci. 2008;7(2):199-208.

41. Sudjarwo SA, Koerniasari. Protective effects of ethanol extract of mangosteen (Garcinia mangostana L) pericarp against lead acetateinduced nephrotoxicity in mice. Glob J Pharmacol. 2015;9(4):385391.

42. Husen SA, Khaleyla F, Ansori ANM, Susilo RJK, Winarni D. Antioxidant activity assay of alpha-mangostin for amelioration of kidney structure and function in diabetic mice. Adva Soc Sci Edu Hum Res. 2018;88:84-88. 